\title{
Efeitos das ações formativas e das concepções epistemológicas nas práticas docentes de uma futura professora de química
}

Camila Greff Passos

José Claudio Del Pino

\begin{abstract}
Resumo
Este trabalho compõe um estudo de caso, no âmbito da formação de professores de Química, que visou analisar o sinergismo entre as concepções epistemológicas e as ações formativas vivenciadas no Curso de Licenciatura em Química Noturno da UFRGS na prática docente de uma licencianda. Nesse sentido, buscou-se identificar os modelos didáticos utilizados por ela nos Planos de Trabalho empreendidos nas Escolas de Educação Básica em que a licencianda realizou seus estágios. Para tanto, utilizou-se do aporte teórico de Rafael Porlán Ariza e Ana Garcia Rivero sobre a evolução do conhecimento profissional docente. Os resultados da investigação evidenciaram que, no período dos estágios, a licencianda progrediu para estágios intermediários do processo de desenvolvimento profissional. Além disso, verificaram-se evidências da interrelação entre as diferentes experiências acadêmicas do curso e as práticas docentes utilizadas pela futura professora. Dessa forma, apontam-se contribuições para o melhor entendimento dos processos de evolução das concepções epistemológicas de professores em formação.
\end{abstract}

Palavras-chave: formação de professores, modelos didáticos, concepções epistemológicas.

\section{Abstract \\ The effects of formation actions and epistemological conceptions in the teaching practices of a future chemistry teacher}

This paper comprises a case study within the scope of Chemistry teacher formation aimed at analyzing the synergism between epistemological conceptions and formative actions experienced in the Licenciate degree in the Chemistry evening course at UFRGS in the teaching practices of an undergraduate teacher. In this sense, the identification of the didactic models used by the undergraduate was sought in the Work Plans employed in Elementary Education Schools in the licencianda held its internships. For such, Rafael Porlán Ariza e Ana Garcia Rivero theoretical foundation on the evolution of teacher's professional knowledge was used. The results of the study made evident that during the internship period the undergraduate progressed to the intermediate stages in the professional development. Furthermore, evidence was found of the interrelation between different academic experiences in the course and the teaching practices used by the future teacher. This way, contributions may be pointed out for a better understanding of the evolution processes of epistemological conceptions of teachers during their formation.

Keywords: teacher formation, didactic models, epistemological

DOI: Em andamento. 


\section{Introdução}

Este estudo é referente a uma das etapas de uma investigação, realizada em nível de doutoramento (PASSOS, 2012), sobre as conquistas e desafios do Curso de Licenciatura em Química Noturno da UFRGS (CLQ), frente à reformulação curricular implementada em 2005, sob orientação das atuais Diretrizes Curriculares Nacionais (DCN), para formação de professores da Educação Básica (BRASIL, 2002).

Dessa forma, neste texto discute-se a análise desenvolvida no decorrer do período letivo do primeiro e segundo semestres de 2009, quando uma licencianda da primeira turma que cursou toda a organização curricular, em vigência desde 2005, vivenciava o período dos Estágios Curriculares Supervisionados. O objetivo maior deste trabalho é diagnosticar se houve evolução do conhecimento profissional da futura professora, através da identificação dos modelos didáticos, associados às concepções epistemológicas, utilizados por ela nos Planos de Trabalho empreendidos nas escolas em que a licencianda estagiou. Com esta investigação, também se buscam verificar os efeitos do conjunto de ações formativas vivenciados no CLQ, analisados em estudos anteriores (PASSOS; DEL PINO, 2012; 2013), na prática docente da licencianda e no seu processo de desenvolvimento profissional.

\section{Referencial teórico}

\section{Concepções epistemológicas}

O estudo das concepções epistemológicas dos professores envolve a análise integrada do sistema de crenças educacionais desses profissionais (KAGAN, 1992; BEACH e PEARSON, 1998), como as suas conviç̧ões sobre o papel do professor e do aluno nos processos de ensino e aprendizagem, com as suas concepções científicas (LENDERMAN, 1992; MELLADO, 2001), como a compreensão sobre a natureza da Ciência e o status do conhecimento científico.

Diversos relatos na literatura apontam que as concepções epistemológicas podem ser consideradas como ferramentas de suporte ou obstáculos ao desenvolvimento profissional docente, haja vista que têm papel organizador da prática e estruturador do conhecimento profissional, embasando assim os modelos didáticos utilizados pelos professores e futuros professores. Nesse âmbito, investigações sobre as concepções epistemológicas dos professores em formação têm contribuído com explicações sobre o porquê de muitas ações formativas não terem um impacto significativo na mudança das práticas docentes implementadas nas Escolas de Educação Básica (HARRES et al., 2008; PORLÁN et al., 2010; PRAIA et al., 2002). 
Soares e Bejarano afirmam que estudar crenças educacionais é "se aproximar do pensamento e das ações dos professores já que sabemos que estes não são movidos apenas pelo conhecimento, mas também e, sobretudo por suas crenças educacionais, mas também de homem, de mundo, dentre outras" (2008, p. 59).

Conforme alguns pesquisadores da área de formação de professores, os docentes de Ciências, em especial, são resistentes à mudança de suas crenças educacionais e concepções científicas, pois que tais foram estruturadas social e culturalmente de forma não reflexiva no período escolar (BEJARANO e CARVALHO, 2003; CARVALHO e GIL-PÉREZ, 2006; SCHNETZLER, 2002), sendo muitas vezes reforçadas por grande parte das atividades dos programas de formação das instituições universitárias, que ainda são norteados pelo reducionismo epistemológico academicista e pelo absolutismo racionalista (HARRES et al., 2005; PORLÁN et al., 2010)

Olafson e Schraw (2006) destacam que cada pessoa tem uma visão epistemológica que define sua atitude em relação à natureza do conhecimento e ao saber adquirido, que é composta por suas crenças educacionais, saberes e conhecimentos. Os autores relatam que se trata de uma perspectiva intelectual atuando como um prisma com a qual se vê o mundo, transcendendo as crenças específicas sobre o conhecimento.

Convergindo com essa compreensão, Porlán e Rivero (1998) apontam que a epistemologia manifestada pelos professores, em respeito ao conhecimento científico, é uma parte substancial de suas perspectivas profissionais, configuradas por uma sucessiva cadeia de reforços ao longo de sua experiência pessoal e profissional.

Frente a esses apontamentos, compreendem-se as concepções epistemológicas como o produto do sinergismo entre as crenças educacionais, as concepções científicas, conhecimentos e saberes interiorizados desde o início da vida escolar do professor e moldados por suas experiências no decorrer de sua vida social, cultural, acadêmica e profissional. Sendo, dessa forma, estruturas pessoais do professor e que podem influenciar percepções e julgamentos que, por sua vez, podem afetar o comportamento desses profissionais em sala de aula e durante o processo de desenvolvimento profissional.

De acordo com as amplas pesquisas realizadas por Porlán e Rivero (1998), o estudo das concepções epistemológicas já vem sendo realizado desde a década de 80 , tendo como um de seus precursores Pope e Scott. Porlán e Rivero (1998) descrevem que os referidos autores defendem a hipótese de que os professores que possuem a concepção positivista e empiroindutivista da Ciência consideram o absolutismo do conhecimento científico e sustentam uma prática docente na qual os conhecimentos e a participação de seus alunos são minimamente ponderados. 
Em revisão mais recente sobre o tema, Mansur (2009) destaca que muitos trabalhos da área têm caráter classificatório, visando à categorização das concepções na perspectiva behaviorista, de transmissão de informações do professor para o aluno, ou na abordagem construtivista, que contempla a participação ativa dos alunos na construção do conhecimento. $O$ autor destaca que mesmo que a classificação pareça simplista, algumas pesquisas demonstraram que as categorias servem de referência aos estudos que buscam a análise dos fatores que levam a mudança das crenças, concepções e práticas dos professores.

De acordo com alguns pesquisadores da área, a linha investigativa é considerada de significativa importância para fundamentar a elaboração de programas de formação que efetivamente favoreçam práticas docentes condizentes com os intentos das pesquisas da Epistemologia e Didática das Ciências, como as norteadas pelas perspectivas construtivistas e investigativas (CARVALHO e GIL-PÉREZ, 2006; PORLÁN et al., 2010; PRAIA et al., 2002; SCHNETZLER, 2002).

Dentre alguns estudos sobre as mudanças das concepções epistemológicas dos professores de Ciências, verifica-se que os autores se referem à ideia de progressão das concepções, estabelecendo estágios intermediários para acompanhar o desenvolvimento profissional docente. Flores et al., (2000), destacam que em suas investigações com professores em formação continuada, foi possível verificar uma mudança gradual de concepções empiristas e behavioristas para posições intermediárias como o positivismo lógico e o cognitivismo, porém uma mudança drástica para o construtivismo os autores destacam que é um processo difícil e complexo. Mellado (2001) avalia que a evolução gradual das concepções dos professores está relacionada a dois tipos de obstáculos, os de contexto, como a organização escolar, o status da profissão e os relativos ao próprio docente, que são suas concepções epistemológicas e mitos culturais sobre o papel do professor e do aluno. O autor ainda destaca alguns fatores que favorecem a evolução das concepções, como a investigação de problemas profissionais, o desenvolvimento de materiais didáticos e a investigação dos obstáculos de progressão.

Em contrapartida, verificam-se algumas críticas a essa temática na literatura. André (2010) e Zeichener (2009) argumentam que as pesquisas da área de formação de professores que tratam sobre as crenças, concepções, saberes e prática dos docentes priorizam uma das pontas da questão, não empreendendo um estudo integrado do impacto da vida escolar e do programa de formação no sistema de crenças, concepções e prática dos futuros professores. Esses autores alertam que é preciso analisar de forma articulada as concepções dos professores, com os processos formativos vivenciados por estes, para assim poder avaliar as suas práticas de ensino.

Frente a esses argumentos, justifica-se este trabalho como um exercício de aproximação a uma abordagem sistemática, que não objetiva apenas a identificação das concepções epistemológicas que embasam os modelos didáticos utilizados pela futura professora, mas busca 
analisar os efeitos das ações formativas vivenciadas no CLQ e das suas concepções epistemológicas nas práticas docentes desenvolvidas nas escolas.

\section{Relações entre os modelos didáticos, as concepções epistemológicas e as ações formativas}

Embora existam variados critérios para caracterizar os modelos didáticos pessoais dos professores (GARCÍA PÉREZ 2000; NOVAIS e MARCONDES; 2008), neste estudo utilizam-se as categorias propostas por Porlán e Rivero (1998), que identificam tais modelos de acordo com as concepções epistemológicas que os fundamentam, analisando-os conforme uma perspectiva evolutiva dentro de uma Hipótese de Progressão do conhecimento profissional.

Porlán e Rivero (1998) realizaram uma ampla pesquisa utilizando o questionário INPECIP (Inventario de Creencias Pedagógicas y Científicas) para elaborar uma Hipótese de Progressão do conhecimento profissional. Com o entendimento de que a epistemologia pessoal engloba o conhecimento escolar e o conhecimento profissional, os autores buscaram determinar tendências epistemológicas gerais que pudessem constituir um eixo vertebrador da hipótese geral de progressão do conhecimento profissional sobre o conhecimento escolar.

Conforme suas investigações, Porlán e Rivero (1998) verificaram que houve a predominância da teoria que compreende o conhecimento escolar como um produto acabado e formal, no qual o ensino se concebe como uma prática diretiva centralizada no discurso cientificista do professor ou do livro texto, sendo a aprendizagem um processo mecânico de absorção desses conhecimentos considerados como verdades absolutas. Nesse contexto, os autores relataram que o conhecimento profissional dominante verificado é resultante da justaposição de quatro saberes de natureza diferente, sendo dois deles de dimensão epistemológica organizados na dicotomia racional-experiencial e os outros dois de dimensão psicológica, atendendo a dicotomia explícito-implícito. Tal característica contribui significativamente para a dificuldade de construir um conhecimento coerente com as atuais demandas da atividade profissional, pois tais saberes teriam sido gerados em momentos e contextos distintos, mantendo-se relativamente separados uns dos outros na memória dos professores e se manifestando em diferentes tipos de situações profissionais ou pré-profissionais.

Para Porlán e Rivero (1998), os quatro saberes que constituem o conhecimento profissional são:

- Saberes acadêmicos: relacionados aos conteúdos disciplinares, psicológicos, didáticos e epistemológicos gerados no processo de formação inicial. Esse tipo de saber é explícito e organizado, atendendo uma lógica disciplinar quanto à influência na prática profissional; 
- Saberes baseados na experiência: relacionados a um conjunto de ideias conscientes desenvolvidas pelos professores durante o exercício profissional sobre diferentes aspectos dos processos de ensino e aprendizagem (a aprendizagem dos alunos, a metodologia, os objetivos, o papel da avaliação). Esses saberes manifestam-se como crenças explícitas e princípios de atuação, normalmente compartilhadas no contexto escolar, tendo forte poder socializador e orientador da conduta profissional;

- Rotinas e guias de ação: referem-se a um conjunto de esquemas implícitos que predizem o curso dos acontecimentos em aula e que contém pautas de ação concretas e padronizadas. As rotinas e guias de ação são saberes gerados lentamente por processos de formação ambiental, que cumprem uma função psicológica e biológica, resistindo a mudanças e simplificando a tomada de decisões e o controle de situações rotineiras;

- Teorias implícitas: referem-se mais a um 'não saber' do que a um 'saber', no sentido de que são as teorias que podem dar razão às crenças e às ações dos professores em função de categorias externas. Não são teorizações conscientes dos professores, pois são interpretações $a$ posteriori sobre as teorias que dão razão ao que cremos e ao que fazemos. Igualmente as rotinas e guias de ação correspondem frequentemente a estereótipos sociais hegemônicos.

Os autores justificam que o conhecimento profissional dominante verificado é consequência de um processo de adaptação e socialização dos professores à cultura escolar tradicional e aos estereótipos sociais dominantes sobre a educação e a escola. Como agravante, os modelos de formação de professores predominantes não promovem um conhecimento profissional que integre adequadamente os conhecimentos teóricos e os conhecimentos baseados na experiência profissional, fazendo com que muitos professores tenham dificuldades para aderir às propostas de ensino de perspectivas construtivistas, como as investigativas (PORLÁN e RIVERO, 1998).

Em estudo recente, Porlán et al., (2010) complementam que o conhecimento profissional predominante é um dos fatores responsáveis pelo fracasso das novas propostas de ensino. Os autores alertam que a mudança na realidade escolar e principalmente no ensino de Ciências é possível, mas que os professores precisam desenvolver um conhecimento profissional menos influenciado pela cultura dominante, ou seja, esse processo está condicionado à modificação das concepções majoritárias dos professores formadores e dos futuros professores. Essas concepções são coerentes com a cultura escolar em que foram formados, estando longe dos princípios sócioconstrutivistas, críticos e relativistas que fundamentam os modelos alternativos de ensino. As novas propostas, diferente das tradicionais, concebem os alunos como sujeitos de aprendizagem, que possuem conhecimentos sobre os fenômenos em estudo e que são capazes de participar efetivamente na investigação de problemas que possibilitem o enriquecimento desses conhecimentos, sendo o professor o orientador dessa investigação. 
Frente a essa realidade, Porlán e Rivero (1998) propõem uma estratégia denominada Hipótese de Progressão, concebida como uma teoria sobre como o conhecimento profissional pode se complexificar em direção a um nível considerado como desejável. Os autores descrevem que se trata de uma estratégia com pretensão de melhoria significativa e progressiva dos sistemas de ideias pré-existentes dos professores e não da sua mera substituição.

\section{Hipótese de progressão do conhecimento profissional}

Porlán e Rivero (1998) estabeleceram uma gradação referente à evolução do conhecimento profissional, desde perspectivas mais simplificadoras, reducionistas, estáticas e acríticas, correspondentes a modelos didáticos mais tradicionais, perpassando níveis intermediários, como o modelo tecnológico e o modelo espontaneísta, que superam em parte o tradicional, mas que ainda apresentam obstáculos a serem superados, até outras perspectivas mais coerentes com modelos alternativos de caráter investigativo e construtivista, considerados como desejáveis. Porém, os autores afirmam que sua hipótese não se constitui em uma receita definitiva e acabada e nem um itinerário inevitável, mas sim, uma proposta que defende um planejamento evolutivo do conhecimento profissional no qual se considera importante tanto o processo quanto o produto.

Dessa forma, destaca-se que o conhecimento profissional desejável pode ser compreendido como um conhecimento epistemologicamente diferenciado e interessado, pois engloba atitudes e valores que visam à transformação do contexto escolar e profissional. Sendo assim, influencia significativamente na maneira de o professor interpretar e atuar no processo de ensino. O conhecimento profissional desejável pode ser considerado um sistema de ideias com diferentes níveis de organização e articulação. Esse sistema de ideias está sujeito a uma reorganização contínua e evolutiva, no qual novos conhecimentos são elaborados a partir de conhecimentos anteriores, através de pequenas ou amplas reestruturações que podem ser concretizadas em diferentes níveis de formulação, indo de uma gradação do simples ao complexo.

Alguns autores descrevem que a passagem de um nível a outro do conhecimento profissional depende de uma série de remodelagens do conhecimento prévio de forma qualitativa (FLORES et al., 2000; MANSUR, 2009; PORLÁN et al., 2010;). A manifestação dos diferentes níveis está atrelada "ao grau de tomada de consciência, controle e superação relativa de diversos obstáculos que dificultam a compreensão dos processos de ensino e aprendizagem em um nível de complexidade superior" (PORLÁN e RIVERO, 1998, p. 93).

A Hipótese de Progressão do conhecimento profissional vem sendo utilizada promissoramente para acompanhar o desenvolvimento profissional de professores de Ciências em programas de formação inicial e continuada (HARRES e PIZZATO, 2007; PORLÁN et al., 2010). De acordo com relatos da literatura, o estudo da evolução dos modelos didáticos presentes nas 
produções escritas e orais dos professores em formação, associados às concepções epistemológicas que os fundamentam, além de possibilitar a discussão sobre a evolução do conhecimento profissional, auxilia na identificação das intervenções metodológicas que mais favorecem o processo de progressão (HARRES et al., 2005; PREDEBON e DEL PINO, 2009; RODRIGUES et al., 2010).

Predebon e Del Pino (2009) descrevem que o estudo sobre os modelos didáticos que um profissional utiliza para exercer sua prática pode representar uma ferramenta de verificação da coerência entre o que ele acredita (crenças e concepções) e o que faz (prática docente). Dessa forma, os modelos didáticos são instrumentos de interpretação da realidade de sala de aula, em um determinado contexto de aplicação, ou seja, constituem diferentes propostas de apreensão da realidade do trabalho docente que expressam a diversidade de concepções sobre o conhecimento, sobre a educação e sobre o mundo. Para García Perez (2000), o modelo didático é um instrumento que facilita a análise da complexa realidade escolar, permitindo a proposição de intervenções com vistas à sua transformação.

\section{Metodologia}

A investigação descrita neste trabalho tem natureza qualitativa, pois se analisou um contexto de sala de aula, frente às suas particularidades, subjetividades e complexidades. Para tanto, a pesquisa foi desenvolvida em uma estrutura analítica integrada através de um Estudo de Caso. Para Yin (2009), o Estudo de Caso deve ser utilizado quando se investiga fenômenos sociais complexos em suas condições contextuais. Segundo Lüdke e André (1986, p.17), “o Estudo de Caso é o estudo de um caso", desta forma, compreende-se que uma determinada situação, por exemplo, mesmo sendo semelhante a outras, torna-se distinta devido as suas características, sujeitos e contexto analisados.

Bogdan e Biklen (2006, p. 89) afirmam que o Estudo de Caso "consiste na observação detalhada de um contexto, ou um indivíduo, de uma única fonte de documentos ou de um acontecimento específico". Entretanto, os autores esclarecem que é favorável coletar dados utilizando diferentes instrumentos, para relacioná-los e confrontá-los, a fim de melhor compreender os fenômenos estudados.

Nesse sentido, primeiramente, efetivou-se a análise documental (LÜDKE e ANDRÉ, 1986) do Projeto Pedagógico do CLQ e dos Planos de Trabalho elaborados por uma de suas licenciandas durante os Estágios Curriculares Supervisionados. A licencianda que participou desta investigação era integrante da primeira turma que cursou toda a organização curricular em vigência desde 2005. A futura professora, assim como seus colegas, respondeu a um questionário, no início do primeiro estágio, que visava à elaboração do perfil acadêmico e profissional da turma. Entende-se 
que informações referentes ao histórico acadêmico e profissional dos licenciandos podem contribuir para a discussão sobre o processo de desenvolvimento profissional.

Como critérios de seleção da licencianda, utilizaram-se a concordância da mesma, a autorização da escola, dos alunos e seus responsáveis, pois as aulas ministradas por ela, em umas das turmas em que estagiou, foram filmadas por um dos pesquisadores. Os planejamentos elaborados pela licencianda foram implementados durante os Estágios Curriculares Supervisionados, em Escolas de Educação Básica da rede pública estadual de ensino, na cidade de Porto Alegre, no ano letivo de 2009. No total foram registradas 60 horas-aula, durante os dois estágios. Para acompanhar as aulas como observador participante, (LÜDKE e ANDRÉ, 1986), elaborou-se um Diário de Campo (PORLÁN e MARTíN, 1998) como instrumento de coleta de dados e como guia de investigação sobre a efetivação das atividades identificadas nos Planos de Trabalho nos dois estágios. Porlán e Martín descrevem que "o diário permite refletir o ponto de vista do autor sobre os processos mais significativos da dinâmica em que se está imerso" (1998, pág. 19).

Os dados coletados foram analisados e interpretados segundo o sistema de codificação proposto por Bogdan e Biklen (2006) que dizem:

"O desenvolvimento de um sistema de codificação envolve vários passos: percorre seus dados na procura de regularidades e padrões bem como de tópicos presentes nos dados, e, em seguida, escreve palavras e frases que representam estes mesmos tópicos e padrões. Estas palavras e frases são categorias de codificação. As categorias constituem um meio de classificar os dados descritivos que recolheu [...]." (BOGDAN e BIKLEN, 2006, p. 221).

É pertinente salientar que, para atingir os objetivos deste estudo, utilizou-se das quatro categorias de análise esquematizadas na proposta de transição e evolução de Modelos Didáticos norteadas na Hipótese de Progressão do conhecimento profissional (PÓRLAN e RIVERO, 1998), sendo estas: Conteúdos Escolares; Uso Didático das Perspectivas dos Alunos; Tipos de Atividades e Recursos Didáticos; Avaliação.

A partir dessas quatro categorias de análise, buscaram-se aproximações dos Planos de Trabalho da licencianda, com as características apontadas pelas Figuras 1, 2, 3 e 4, para as respectivas categorias. Essas figuras referem-se a como os futuros professores abordam os conteúdos escolares em seus Planos de Trabalho, como utilizam e se utilizam as perspectivas dos alunos, quais os tipos de atividades e recursos didáticos são priorizados e, por último, as formas de avaliação. 


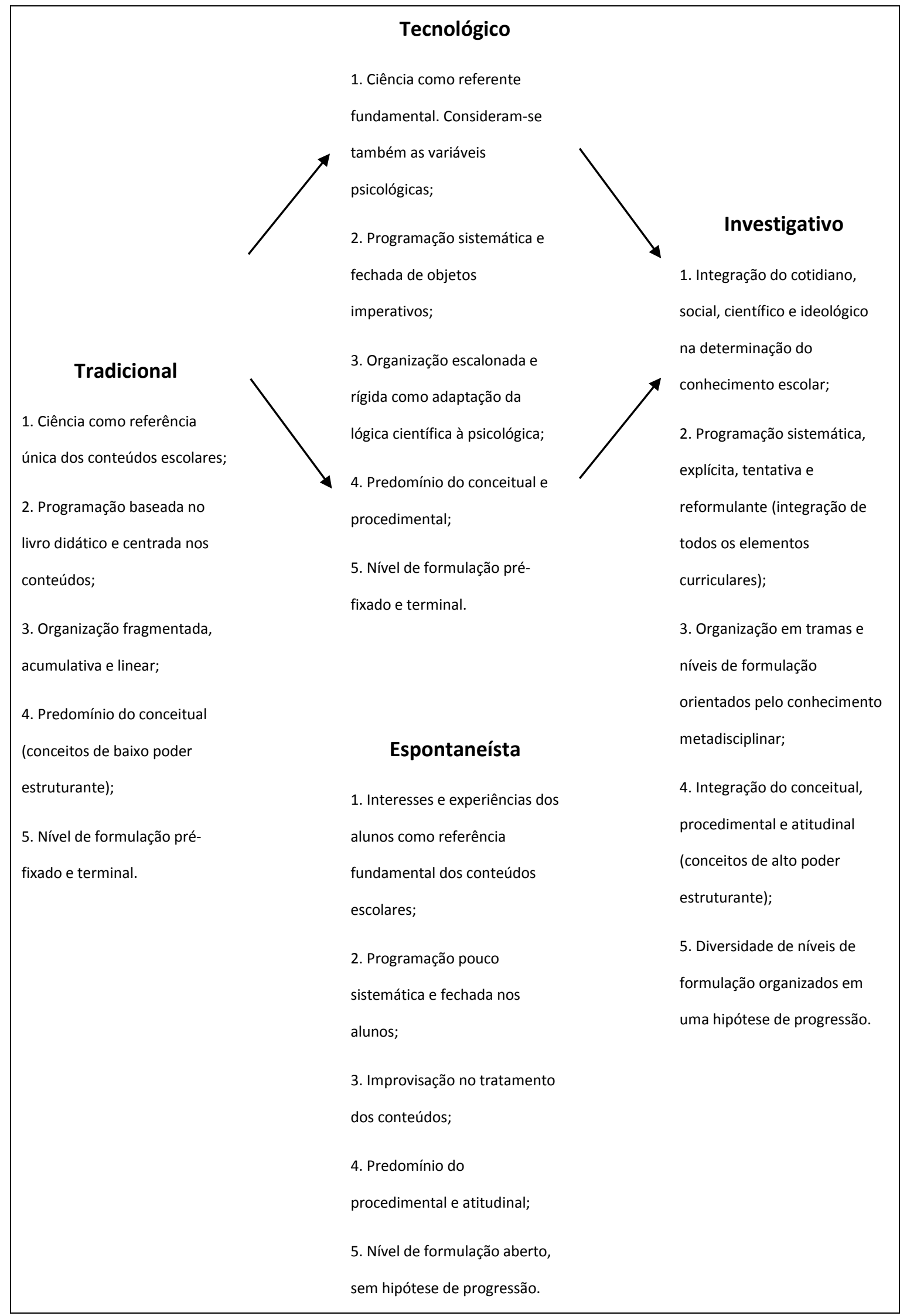

Figura 1- Transição proposta em relação com os Conteúdos Escolares.

(Fonte: Traduzido e adaptado de Porlán e Rivero, 1998, p.158.) 


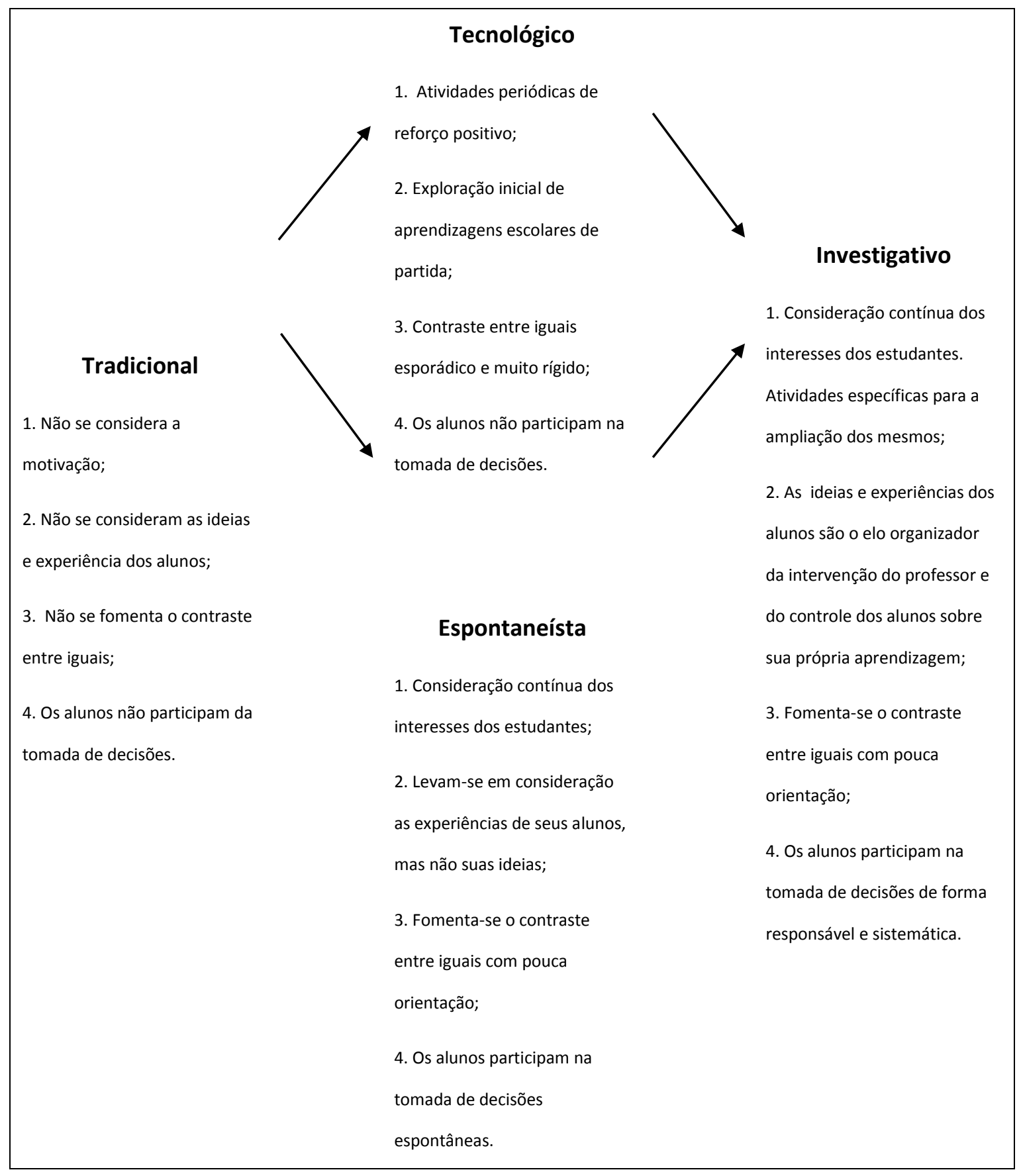

Figura 2- Transição proposta em relação com o Uso Didático da Perspectiva dos Alunos.

(Fonte: Traduzido e adaptado de Porlán e Rivero, 1998, p.158.) 


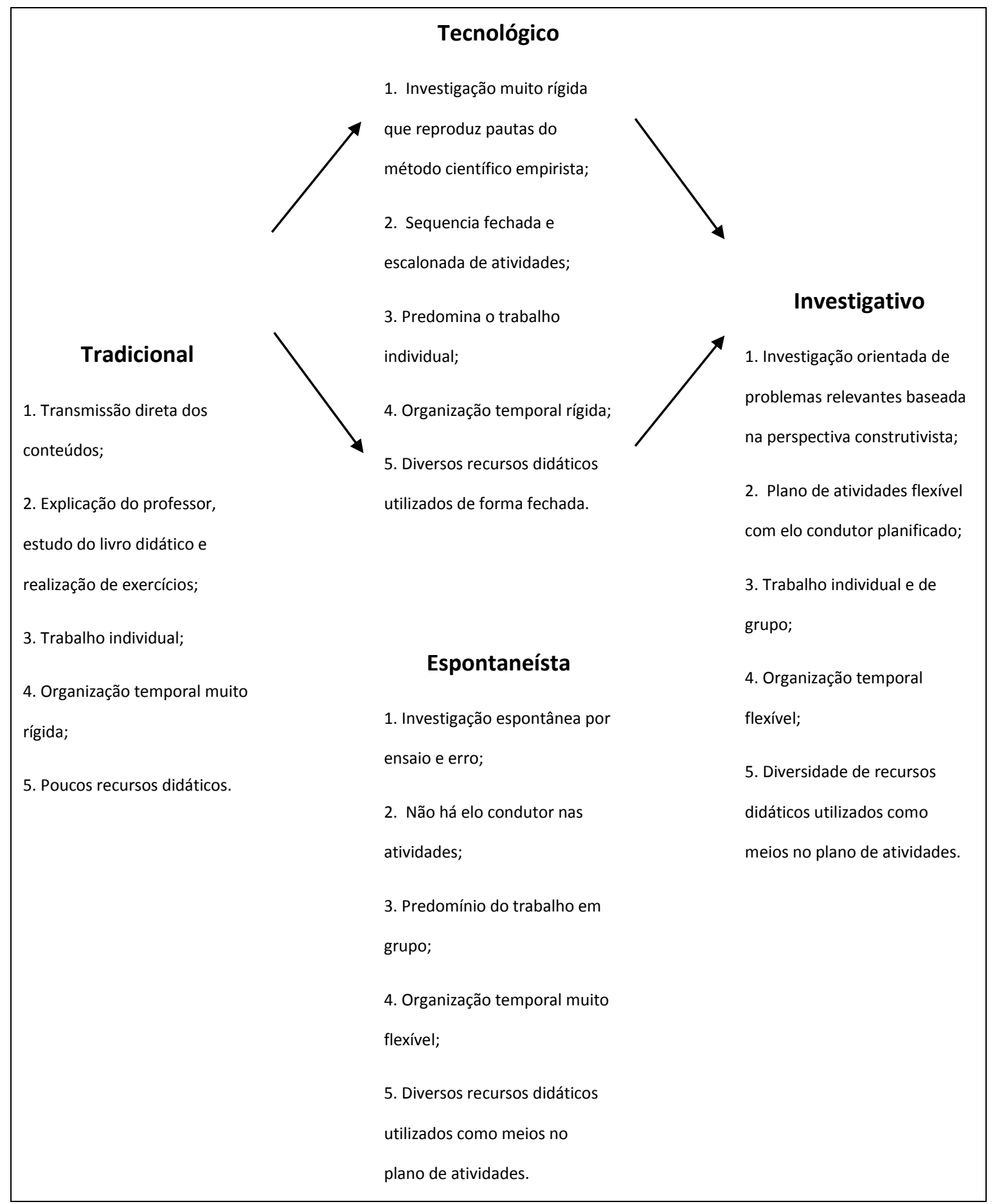

Figura 3- Transição proposta em relação com os Tipos de Atividades e Recursos Didáticos.

(Fonte: Traduzido e adaptado de Porlán e Rivero, 1998, p.159.) 


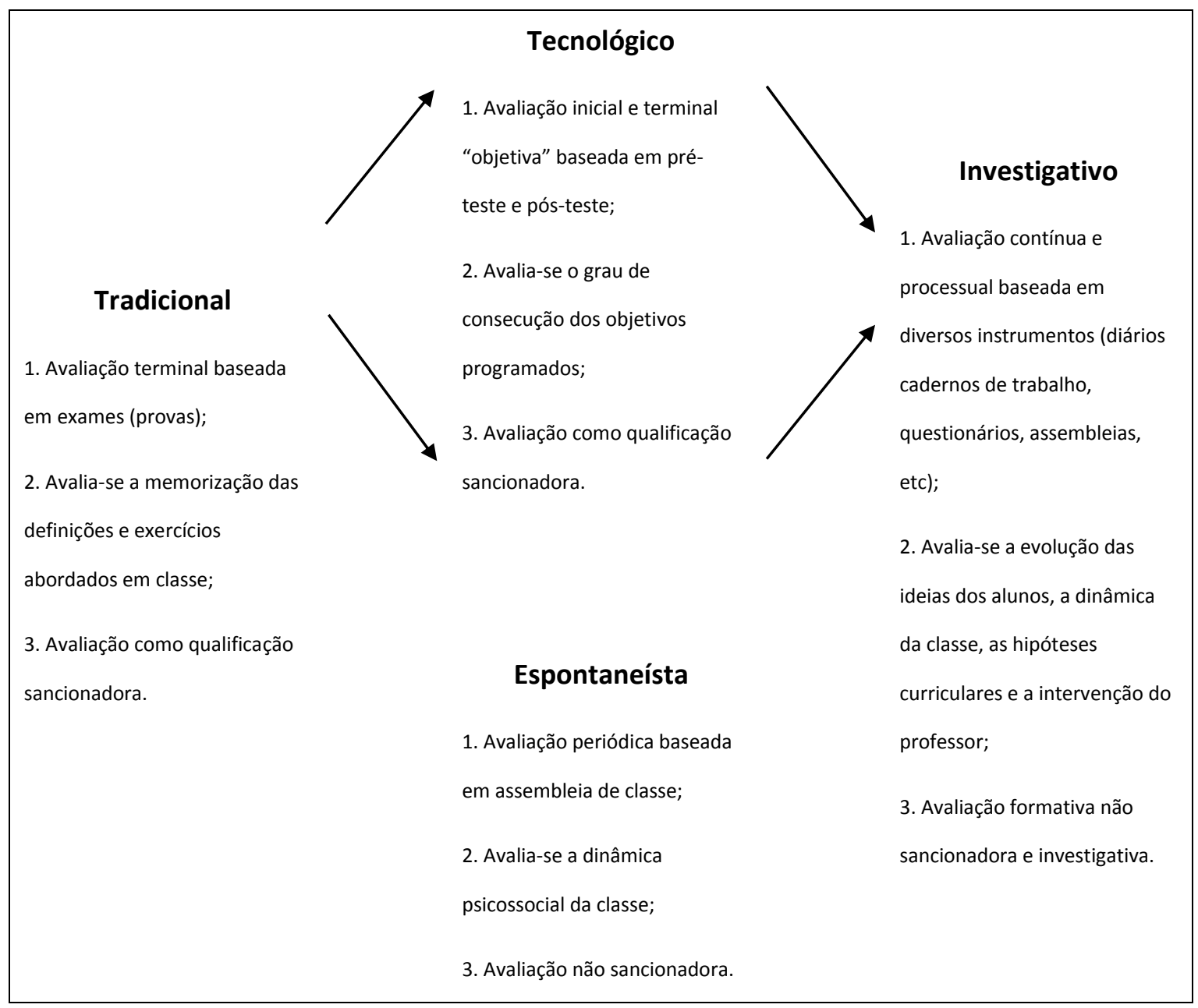

Figura 4- Transição proposta em relação a Avaliação.

(Fonte: Traduzido e adaptado de Porlán e Rivero, 1998, p.160.)

Na sequência, relacionaram-se as características das ações formativas do CLQ, analisadas em estudos anteriores (PASSOS; DEL PINO, 2012; 2013), com os Modelos Didáticos utilizados pela licencianda, na busca de identificar o sinergismo entre as atividades vivenciadas no CLQ, as concepções epistemológicas da licencianda e as práticas desenvolvidas nas escolas em que ela estagiou.

\section{Resultados e discussão}

\section{o Curso de Licenciatura em Química Noturno da UFRGS (CLQ)}

O currículo do CLQ está dividido em 10 etapas, apresentando uma carga horária total de 3165 horas, distribuídas em quatro grupos de disciplinas e atividades: i) $420 \mathrm{~h}$ de práticas de ensino, voltadas à formação pedagógica em geral, na qual 300 h são de disciplinas Pedagógicas

DOI: Em andamento. 
obrigatórias e 120 h de eletivas; ii) 420 h de estágios de docência; iii) 2115 h de disciplinas Específicas, focadas na formação dos conhecimentos das áreas de Química, Física e Matemática, na qual $1695 \mathrm{~h}$ são de específicas obrigatórias, $120 \mathrm{~h}$ de específicas eletivas e $300 \mathrm{~h}$ de Articuladoras entre os conhecimentos pedagógicos e químicos, juntamente com aqueles oriundos das pesquisas na área de Ensino de Química; iv) $210 \mathrm{~h}$ de atividades complementares, nas quais o aluno pode escolher entre extensão universitária, atuação como Iniciação Científica, representação discente junto aos órgãos da Universidade, participação efetiva e comprovada em semanas acadêmicas, congressos, entre outros (UFRGS, 2005).

No que diz respeito à distribuição das 420 horas de estágios curriculares supervisionados, de 2005 até 2011, o CLQ apresentava essa carga horária distribuída na forma de duas disciplinas: Estágio em Ensino de Química IA de 12 créditos e o Estágio em Ensino de Química IIA de 16 créditos. No Estágio IA, os alunos tinham 76 horas/aula de atividade de docência e no Estágio IIA 112 horas/aula. Destaca-se que no decorrer do texto serão apresentadas, de forma objetiva, outras características sobre o conjunto de ações formativas do CLQ.

\section{A Licencianda Sil}

A licencianda que participou desta investigação foi chamada de Sil, pois sua verdadeira identidade foi mantida em sigilo. Sil tinha 31 anos de idade no período da investigação. Quanto à formação escolar e acadêmica, ela cursou técnico em Química e trabalhou na área técnica de formação por 6 anos. Na época da pesquisa, ela foi bolsista de iniciação científica na Área de Educação Química da UFRGS (AEQ), por 12 meses. Sil nunca havia atuado como professora antes da experiência dos estágios. Quando questionada sobre os motivos que influenciaram a escolha pelo $C L Q$, a licencianda apontou que foi devido à decepção em outra área de atuação profissional.

\section{Modelos Didáticos da Licencianda Sil - Estágio IA}

O Plano de Trabalho da Licencianda Sil para o primeiro estágio foi elaborado para duas turmas do 2 o ano do ensino médio de uma Escola da rede pública estadual de Porto Alegre. Conforme os relatos de Sil, suas atividades foram estruturadas seguindo o calendário escolar, o Projeto Político Pedagógico da Escola, as orientações do professor orientador do estágio e as combinações com o professor regente das turmas.

Sil organizou seu Plano de Trabalho numa sequência de dez aulas de três períodos, ou seja, dez semanas de trabalho com três períodos cada, explicitando o objetivo de cada aula, assim como as atividades e recursos didáticos utilizados. Somente sobre os instrumentos avaliativos a licencianda não descreveu detalhadamente suas intenções, mas suas pretensões ficaram implicitamente claras. 
De acordo com os registros dos pesquisadores no Diário de Campo, Sil conseguiu efetivar seus planejamentos no primeiro estágio, de forma convergente com as características das categorias identificadas no Plano de Trabalho.

A licencianda apontou que sua proposta de trabalho daria continuidade às atividades realizadas pelo professor titular no período em que observou as turmas. Sil descreveu que ficou responsável por desenvolver os conteúdos referentes às Soluções e à Estequiometria.

Na primeira aula, Sil aplicou um questionário com seus alunos, visando conhecer melhor a rotina escolar e social, a faixa etária da turma e os interesses deles no estudo da Química. Para este último objetivo, a licencianda elencou temáticas que ela considerou relacionáveis aos conteúdos que deveriam ser trabalhados ao longo de seu primeiro estágio. A temática escolhida pela maioria dos alunos foi consumo consciente da água.

Conforme os relatos, em seus planejamentos, Sil almejava aproximar o estudo dos conteúdos escolares aos acontecimentos do cotidiano dos alunos, como se pode exemplificar com os trechos abaixo:

[Semana 02] Objetivos: "Informar aos alunos sobre a importância do uso consciente da água e ilustrar a relação da Química com o nosso cotidiano; Apresentar como preparar uma solução e como calcular a sua concentração; Exercitar a classificação dos tipos de soluções".

[Semana 05] Objetivos: "Demonstrar a queima do papel e da palha de aço, pois são fenômenos próximos aos que os alunos vivenciam em suas casas ou na infância. Considero que são exemplos que facilitarão a compreensão deles sobre as Leis Ponderais; Apresentar as Leis Ponderais; Introduzir as regras de balanceamento das reações." (grifo nosso)

Entretanto, nos planejamentos elaborados para o primeiro estágio, percebe-se que mesmo com a intenção de contextualizar os conhecimentos científicos com os fatos do dia a dia dos alunos, como declarado pela licencianda, ela considerou o conteúdo científico como principal referente dos conteúdos escolares, visto que sua proposta de trabalho foi amplamente dirigida à exposição dos conhecimentos disciplinares da Química. Conforme registros do Diário de Campo (Semana 02), até mesmo as informações sobre a temática água foram apresentadas de maneira breve e expositiva, sem maiores preocupações quanto à integração de tal tema com os fenômenos, representações e teorias descritas no Plano de Trabalho, como se ilustra com os trechos a seguir: 
[Semana 02] Metodologia: "Apresentar no início da aula algumas características físicas e químicas da água, as fontes de abastecimento de água da escola e das residências dos alunos, as estações de tratamento da água e os principais processos de tratamento, além de informações sobre como diminuir o consumo ou como reutilizar a água. Na sequência, fazer a introdução de Soluções, tipos de soluções, mistura de soluções e cálculo das concentrações, fazendo uma demonstração de como preparar soluções usando suco em pó colorido. Entregar e ler com os alunos um material xerocado com as definições dos tipos de soluções e um resumo com as fórmulas dos cálculos de concentração de soluções".

[Semana 06] Metodologia: "Resolver exercícios com os alunos para ilustrar a aplicação das regras de balanceamento das equações que representam reações químicas do tipo combustão e neutralização".

[Semana 07] Metodologia: "Revisar os conteúdos já trabalhados e aplicar exercícios de revisão para a preparação para a prova de recuperação que será sobre soluções." (grifo nosso).

Como se pode perceber, mesmo que a licencianda objetivasse despertar nos alunos o interesse pelo estudo da Química, questionando-os sobre uma temática que gostariam de estudar, ela não buscou relacionar os referentes científicos, sociais e ambientais que poderiam ter sido trabalhados com o estudo do tema água. Sil também não oportunizou aulas práticas nas quais os seus alunos realizassem os experimentos, apenas fez demonstrações ilustrativas, conforme se presenciou em algumas aulas (Diário de Campo - Semana 02 e 05). De acordo com os registros dos documentos analisados nesta investigação, as práticas não visavam à discussão sobre os fenômenos presenciados nas aulas, mas sim comprovar ou elucidar as teorias que estavam sendo estudadas. Dessa forma, entende-se que Sil não apresentava a preocupação com o desenvolvimento do âmbito procedimental que pode ser realizado em uma aula prática, na qual os alunos efetivamente realizam o experimento, elaboram e testam hipóteses, concluem e discutem os diferentes resultados. Assim como, com o desenvolvimento do âmbito atitudinal referente às relações entre o fenômeno estudado e o seu cotidiano, ao consumo consciente dos recursos naturais, ou da conscientização sobre a emissão de gases poluentes, como poderiam ter sido propostos no caso do experimento demonstrado na aula 05.

Segundo Zabala (1998), os conteúdos são de natureza conceitual, procedimental e atitudinal. São conceituais por conterem conceitos, fatos e princípios, isto é, por expressarem o que se deve saber sobre. Os procedimentais se referem a técnicas e métodos, ao que se deve saber fazer, enquanto que os atitudinais abrangem valores, atitudes e normas.

196 DOI: Em andamento.

R. Bras. de Ensino de C\&T 
Enfim, sobre a categoria Conteúdos Escolares (PORLÁN e RIVERO, 1998) considera-se que a licencianda Sil aproximou-se fortemente do modelo didático Tradicional, por ter elaborado um Plano de Trabalho centrado na perspectiva da transmissão dos conteúdos científicos, numa sequência linear e pré-estabelecida destes, contemplando experimentos demonstrativos a fim de exemplificar o conteúdo que seria exposto.

Cabe salientar que a licencianda não fez referência quanto à consideração das concepções e ideias dos alunos, para a elaboração e desenvolvimento das aulas. Como já se descreveu, Sil apenas realizou um levantamento inicial sobre uma temática de interesse dos alunos, mas que não foi utilizada como tema gerador das aulas, e nem mesmo como assunto para ser investigado e discutido com, e pelos alunos (Diário de Campo - Semana 02). A única referência de questionamentos que possibilitou a participação dos educandos está presente no plano da aula 05, quando ela demonstrou a queima do papel e da palha de aço. Conforme o trecho abaixo, a licencianda questionou seus alunos se a massa dos materiais, após a queima, seria menor ou maior do que a determinada anteriormente. Porém não solicitou que eles explicassem o porquê, ou que formulassem uma hipótese sobre os resultados alcançados, já que as equações que representam as reações em questão seriam apresentadas aos alunos:

[Semana 05] Metodologia: "Primeiramente questionar os alunos sobre o que acontecerá com a massa de papel e de palha de aço, se ficará maior ou menor, após a queima. Na sequência, escrever no quadro as duas equações que representam as reações de combustão do papel e da palha de aço e realizar a demonstração. Orientar os alunos para que eles façam o balanceamento das equações. Passar alguns exercícios de balanceamento de reações." (grifo nosso).

Diante desses apontamentos, salienta-se que quanto à categoria Uso Didático da Perspectiva dos Alunos (PORLÁN e RIVERO, 1998) o Plano de Trabalho da licencianda Sil encontrase vinculado ao modelo didático Tradicional, assim como ao modelo didático Tecnológico. Sil não fez referência da utilização das ideias e experiências dos seus alunos sobre os conteúdos trabalhados (modelo tradicional). Porém, fez o levantamento de seus interesses na primeira aula, e os questionou sobre o resultado esperado para o experimento da quinta aula (modelo tecnológico), contudo sem considerar o papel epistêmico dos conhecimentos prévios dos alunos no processo de aprendizagem. Comportamento recorrente na literatura, para professores de Ciências em formação (HARRES et al., 2008).

Dessa forma, compreende-se que a licencianda pensou em instigar o interesse da turma (modelo tecnológico), porém não conseguiu elaborar uma atividade que relacionasse as ideias prévias dos alunos com os novos conhecimentos, apresentando apenas algumas informações de caráter ilustrativo sobre o consumo consciente da água. Sendo assim, a participação dos alunos em aula foi meramente a de espectadores e receptores de conhecimentos expostos pela 
licencianda (modelo tradicional), até mesmo na aula em que ela os questionou sobre a massa da palha de aço e do papel. Conforme os dados apontados no Diário de Campo (Semana 05), não foram realizadas discussões sobre as práticas demonstrativas, apenas verificou-se que os alunos observaram o que a professora-estagiária realizou.

De acordo com o relato do Plano de Trabalho descrito acima sobre a prática, não há evidências quanto à utilização das respostas advindas dos alunos, pois o interesse estava em apresentar as regras de balanceamento de equações, e não em discutir a relação entre o fenômeno demonstrado, suas representações e as teorias das Leis Ponderais. Enfim, a atividade objetivava apenas o entendimento ou a comprovação do conhecimento científico, bem característico de uma perspectiva tecnológica.

Quanto aos Tipos de Atividades e Recursos Didáticos (PORLÁN e RIVERO, 1998), considerase que mesmo que a licencianda tenha se preocupado em trazer experimentos demonstrativos em duas de suas aulas, nas demais os recursos foram majoritariamente o quadro negro e listas de exercícios. Logo, entende-se que quanto a essa categoria, mais uma vez, Sil se aproxima do modelo didático Tradicional e do Tecnológico, visto que buscou utilizar recursos diferenciados, porém se focou na transmissão verbal dos conteúdos, propondo atividades que não favoreceram a participação dos alunos em sua elaboração e execução, visando apenas aplicar ou verificar os conhecimentos que foram apresentados pela licencianda.

Conforme informado na descrição sobre o Plano de Trabalho de Sil, ela não detalhou seus objetivos quanto à escolha pela utilização de provas e trabalhos como únicos instrumentos avaliativos. Percebe-se nos trechos que serão descritos abaixo, que a licencianda não teve liberdade de escolha quanto à utilização destes dois instrumentos:

[Semana 04] Objetivos: "Revisão de conteúdos; Avaliar os conhecimentos dos alunos sobre grandezas químicas e soluções".

Metodologia: "Revisar os conteúdos, resolver exercícios; Aplicar a prova trimestral, pois a Escola tem semana de provas em seu calendário".

Material: "Utilizarei uma prova parecida com a utilizada pelo professor regente, visando a uma homogeneidade de trabalho entre as turmas".

Avaliação: "A prova tem peso de $50 \%$ da nota do trimestre".

[Semana 08] Metodologia: "Revisar o conteúdo de Soluções e Estequiometria, pois os alunos terão prova de recuperação nessa semana. Resolver exercícios".

Material: "Aplicarei a prova de recuperação elaborada pelo professor regente".

198 DOI: Em andamento.

R. Bras. de Ensino de C\&T 
[Semana 09 e 10] Objetivos: "Apresentação oral e demonstração dos experimentos e trabalhos que serão apresentados na Feira de Ciências, conforme combinado com o professor regente".

Metodologia: "Realizar a avaliação dos trabalhos conjuntamente com 0 professor regente. Cada grupo terá 20 minutos para apresentar".

Avaliação: "A nota da apresentação será somada à nota da prova". (grifo nosso).

Entretanto, mesmo frente à obrigatoriedade de utilizar uma prova, ela optou em elaborar um instrumento similar ao do professor regente e, no caso da recuperação, o próprio instrumento utilizado pelo regente. Ao analisar-se a prova, verificou-se que essa somente questionava a aplicação direta dos conteúdos trabalhados em aula, contendo questões sobre a classificação dos tipos de soluções, de cálculos de concentração e de balanceamento de equações químicas. No instrumento, não foi feito nenhum questionamento sobre a apresentação realizada pela licencianda sobre o consumo consciente da água.

Sil também não descreveu o que consideraria para avaliação dos trabalhos que seriam apresentados, apenas informou que nas últimas duas semanas de aula o professor regente acompanharia as atividades em sala. Conforme os dados do Diário de Campo (Semana 09 e 10), o professor regente apresentou os critérios de avaliação para a turma.

Diante do exposto, entende-se que a licencianda Sil considerou que seus instrumentos avaliativos deveriam apenas testar a aplicação ou a memorização dos conteúdos que foram trabalhados em aula. Salienta-se, também, que não se identificou, nos planos das demais aulas, nenhuma referência quanto à consideração da participação dos alunos, ou da avaliação do processo de aprendizagem, apenas do produto que pôde ser expresso na prova ou apresentado no trabalho. Sendo assim, infere-se que os procedimentos de Avaliação (PORLÁN e RIVERO, 1998) adotados por Sil aproximam-se do modelo didático Tradicional.

\section{Modelos Didáticos da Licencianda Sil - Estágio IIA}

No segundo estágio, o Plano de Trabalho da Licencianda Sil também foi elaborado para o 2o ano do ensino médio, porém de outra Escola da rede pública estadual de Porto Alegre, onde ela estagiou em três turmas. Conforme os relatos de Sil, suas atividades foram estruturadas seguindo o Projeto Político Pedagógico da Escola, todavia com a liberdade de escolha dentre os conteúdos que considerasse mais relevantes dentro da Termodinâmica.

Sil organizou seu Plano de Trabalho numa sequência de dez aulas de três períodos, no qual detalhou o objetivo de cada aula, as atividades e recursos didáticos, assim como os 
instrumentos avaliativos que foram utilizados no segundo estágio. Conforme relato da licencianda, sua proposta de trabalho não foi vinculada às atividades realizadas pelo professor titular no período em que observou as turmas, pois ela iniciou seu estágio posteriormente às férias escolares, introduzindo o estudo sobre Termoquímica.

Nos planejamentos desse segundo estágio, Sil não fez referência à utilização de um tema de trabalho e não citou se fez o levantamento inicial com a turma sobre uma temática de interesse dos estudantes, como no primeiro estágio. Porém, ela afirmou que utilizaria os conhecimentos prévios dos seus alunos sobre os conteúdos que seriam estudados, buscando instigá-los a participar das aulas e das atividades propostas, discutindo sobre situações cotidianas que exemplificassem a aplicação dos conhecimentos científicos na vida dos alunos, conforme se ilustra com os trechos abaixo:

[Semana 01] Objetivos: "[...] Revisar o que é uma reação química, como identificar um processo químico, como balancear e ler uma equação química e as leis que regem as reações químicas. Introduzir o estudo da Termoquímica, buscando identificar as ideias dos alunos sobre calor, temperatura, frio, energia, para definir com eles esses conceitos através da discussão sobre fatos que eles presenciam em seu cotidiano (uso do termômetro, vestir blusa de lã no inverno, segurar objeto de madeira e de ferro), motivando-os a participar das aulas e do estudo da Química".

Metodologia: "Após minha apresentação, aplicarei o questionário de levantamento de informações dos alunos. Na sequência, levarei os alunos para o laboratório de ciências, para demonstrar a prática da queima de papel e da palha de aço. Primeiramente questionarei os alunos sobre o que acontecerá com a massa de papel e de palha de aço, demonstrando como os pratos da balança sobem ou descem de acordo com a variação da massa. Perguntarei: Como identificar que está ocorrendo uma reação química? Como representar a reação química demonstrada. O que levou o prato da balança a subir ou descer? Na sequência, escreverei no quadro as duas equações que representam as reações de combustão do papel e da palha de aço e questionarei se eles lembram o que são produtos, reagentes, como balancear as reações, mostrarei a equivalência de massa entre produtos e reagentes. Escreverei no quadro as respostas dos alunos, para definir com eles os conceitos que estão sendo revisados, ou reelaborá-los quando necessário [...]".

[Semana 02] Objetivos: "Estudo da Termoquímica: calor, energia, processos endotérmicos e exotérmicos". 
Metodologia: "Verificar com os alunos as definições que eles pesquisaram sobre calor, temperatura e energia e concluir junto com eles os conceitos que utilizaremos em aula, a partir das suas colocações individuais, para reelaborálas quando necessário. Revisar as mudanças de estado físico, apresentando exemplos (como a fusão do gelo em um copo de refrigerante, a roupa secando no varal) e questionando o nome de cada processo e o que é necessário para que cada processo ocorra, visando estudar processos endotérmicos e exotérmicos. Aplicar exercícios sobre os conceitos trabalhados". (grifo nosso).

Diante do exposto, conclui-se que novamente a licencianda Sil referiu que instigaria seus alunos demonstrando ou descrevendo situações que fossem vivenciadas por eles em seu dia a dia, mas como ela mesma afirma, para motivá-los ao estudo dos conteúdos da Química. Tanto no Plano de Trabalho, quanto nos registros do Diário de Campo (Semana 01, 02 e 03), não se identificou nenhuma atividade que explicitamente integrasse ou contemplasse os referentes sociais, ambientais e econômicos envolvidos nos exemplos discutidos nas aulas, indicando que o referente fundamental dos Conteúdos Escolares dos planejamentos de Sil foi o conhecimento disciplinar da Química. Apenas nas duas últimas semanas de aula, os alunos entregaram e apresentaram um trabalho de pesquisa realizado sobre as diferentes fontes de energia utilizadas no Brasil. Entretanto, a licencianda não elaborou atividades preliminares, nas aulas que antecederam as apresentações, que integrassem o tema que deveria ser pesquisado pelos alunos, com os tópicos de termoquímica trabalhados em aula (Diário de Campo das Semanas 05, 06, 07 e 08).

Contudo, nesse segundo estágio verificaram-se algumas evoluções no Plano de Trabalho de Sil, assim como na prática docente observada em sala de aula, pois a licencianda relacionou os fenômenos discutidos com as representações e teorias que foram trabalhadas. Enfatiza-se, também, que a licencianda considerou as ideias e conhecimentos dos alunos para o desenvolvimento das atividades, através de vários questionamentos em aulas do tipo expositivodialogadas. Todavia, compreende-se que essa metodologia teve como finalidade favorecer a assimilação dos conteúdos de maior grau de formalização que estavam sendo trabalhados, por intermédio da discussão sobre determinadas situações cotidianas, visando à reformulação dos saberes anteriores dos alunos considerados como errôneos ou distorcidos, pois ela enfatiza que "estes serão reformulados quando necessário" nos planos das semanas 01 e 02.

É pertinente destacar que a licencianda não descreveu se consideraria os questionamentos levantados pelos alunos, se valorizaria a troca de ideias e experiências como forma de aprendizagem, ou se fomentaria a socialização dessas ideias, visando a um trabalho colaborativo no estudo dos fatos cotidianos, em busca da complexificação dos conhecimentos dos alunos. Também não se presenciaram atividades dessa natureza, conforme apontamentos do Diário de Campo. Sendo assim, quanto à categoria Conteúdos Escolares (PORLÁN e RIVERO, 1998), 
considera-se que a licencianda Sil utilizou o modelo didático Tecnológico, no qual a aprendizagem é concebida como um processo de assimilação dos conhecimentos científicos, através do uso de uma sequência de atividades na qual os alunos participam de sua execução, porém não de sua elaboração, conforme se observou durante as aulas que foram acompanhadas no segundo estágio.

Diante dessas evidências, subentende-se que Sil, mesmo não referindo, além do âmbito conceitual, buscou desenvolver o âmbito procedimental em seus planejamentos, através de atividades como a pesquisa dos conceitos estudados por parte dos alunos, do exercício da fala e exposição dos resultados e opiniões, da associação de situações cotidianas com os conteúdos científicos. Entretanto, não se identifica nenhuma atividade que visasse ao desenvolvimento do âmbito atitudinal, uma dinâmica bem característica da perspectiva tecnológica.

A perspectiva tecnológica também foi identificada para a categoria Tipos de Atividades $e$ Recursos Didáticos (PORLÁN e RIVERO, 1998). Como exemplo, citam-se as atividades elaboradas para as aulas das semanas 01 e 02 (descritas acima) que apresentam objetivos muito semelhantes aos das aulas 04 e 05 (apresentadas abaixo), das quais os alunos participariam quando questionados sobre os possíveis resultados da prática, ou emitindo suas opiniões individualmente sobre os fenômenos e situações descritos pela licencianda, ou ainda, relatando os conceitos que foram pesquisados:

[Semana 04] Objetivos: "Estudo da Termoquímica: entalpia, cálculos de variação de entalpia, reações endotérmicas e exotérmicas, interpretação de gráficos de variação de entalpia".

Metodologia: "Fazer o fechamento do conceito de entalpia com os alunos, considerando as definições que eles pesquisaram e apresentaram individualmente em aula, para que todos tenham definições coerentes com as referências bibliográficas utilizadas na escola. Questionar os alunos sobre qual o resultado esperado para a variação de entalpia das reações de combustão que serão analisadas através dos gráficos. Apresentar os conceitos de reação endotérmica e exotérmica. Aplicar exercícios sobre cálculos de variação de entalpia e conceitos trabalhados".

[Semana 05] Objetivos: "Estudo da Termoquímica: entalpia, cálculos de variação de entalpia, reações de combustão dos principais combustíveis veiculares utilizados no Brasil".

Metodologia: "Questionar a turma sobre quais os principais combustíveis que são utilizados nos veículos brasileiros. Demonstrar a reação de combustão do álcool etílico e da gasolina, e indicar o valor de entalpia destas reações. Ilustrar 
como calcular a entalpia a partir das entalpias padrões de formação dos reagentes e produtos e da entalpia padrão de combustão. Entregar um texto sobre as principais vantagens e desvantagens da utilização do álcool e da gasolina. Os alunos deverão ler o texto individualmente e responder às questões interpretativas sobre a leitura para entregar". (grifo nosso).

Sendo assim, compreende-se que essas atividades demonstram o interesse da licencianda em fazer com que seus alunos relatassem suas opiniões e interpretações, como eles fizeram em várias aulas, porém com a finalidade de que todos os estudantes estruturassem respostas ou definições de forma convergente a um resultado pré-estabelecido pela teoria estudada, ou defendida pelo livro didático utilizado na Escola.

Além disso, mesmo que a licencianda tenha diversificado os tipos de atividades e a metodologia das aulas, nesse segundo estágio as leituras e pesquisas que ela orientou apresentam roteiros pré-definidos, as leituras são informativas com fim em si mesmas, os exercícios são constituídos por perguntas e respostas de múltipla escolha, além de questionamentos orais com posterior proposição de pesquisa bibliográfica, entre outros. Dessa forma, entende-se que a licencianda aproximou-se do modelo didático Tecnológico, no sentido da proposição de atividades que vão ao encontro de procedimentos pré-determinados e que reproduzem o método científico, visando ilustrar ou verificar os conhecimentos que foram apresentados por ela. É pertinente salientar que os procedimentos didáticos utilizados por Sil, no segundo estágio, são convergentes aos utilizados por professores em início de carreira ou no período final do processo de formação inicial (HARRES et al., 2005; PREDEBON e DEL PINO, 2009; RODRIGUES et al., 2010).

Nesse âmbito, salienta-se que quanto à categoria Uso Didático da Perspectiva dos Alunos (PORLÁN e RIVERO, 1998), o Plano de Trabalho da licencianda Sil mais uma vez se aproximou do modelo didático Tecnológico, pois Sil é enfática quando descreve que considerará os conhecimentos prévios dos alunos, porém para fins motivacionais, visando reformulá-los quando julgar que tais não estejam adequados aos referentes da Ciência. Nas atividades já descritas, assim como nas demais que foram acompanhadas (Diário de Campo das Semanas 02, 04, 05), verificam-se evidências de uma concepção tecnológica, pois a licencianda utiliza-se de perguntas e de questionamentos antes e durante as demonstrações práticas ou exposições argumentativas, como subsídio para a construção de materiais escritos pelos alunos e que servirão de material de apoio, para que ela possa acompanhar a adequação desses em relação aos conteúdos estudados. Ou seja, ela utiliza o estudo de situações cotidianas, para realizar o levantamento das ideias prévias dos alunos, porém com a finalidade imperativa de ilustrar a aplicação do conhecimento científico, buscando que seus alunos assimilem esse conhecimento, considerado por ela, como de hierarquia superior aos demais conhecimentos que compõem o conteúdo escolar. 
No Plano de Trabalho do segundo estágio, Sil descreveu os objetivos e os diferentes instrumentos avaliativos que utilizou. Conforme os relatos do Diário de Campo, verifica-se que no primeiro dia de aula ela expôs à turma que consideraria a participação de cada aluno nas apresentações, pesquisas e atividades realizadas em aula e nas tarefas de casa. Percebe-se, nos trechos que serão descritos abaixo, que diferentemente do primeiro estágio, ela pode escolher os instrumentos avaliativos, desde que um desses fosse uma prova, conforme orientações do Projeto Pedagógico da Escola e do acordo tratado com o professor regente.

[Semana 01] Objetivos: "Apresentação da professora e da proposta de trabalho. Aplicar o questionário com os alunos, para conhecer a faixa etária da turma e os hábitos escolares e sociais do grupo [...]".

Metodologia: "Farei minha apresentação e explicarei que eles serão avaliados através da aplicação de uma prova trimestral com questões objetivas, conforme normatiza o Projeto Pedagógico da Escola, e que o restante da nota será composto pela avaliação individual que farei em todas as aulas, através do registro em uma planilha, do desempenho deles nos aspectos produtivos (realização das atividades) e participativos (apresentação de ideias, pesquisas e respostas)[...]". (grifo nosso).

[Semana 02 e 04] Avaliação: "Participação em aula, apresentação dos conceitos pesquisados, realização dos exercícios".

[Semana 05] Avaliação: "Participação em aula, realização da leitura e entrega do questionário".

[Semana 09] Avaliação: "Prova trimestral. Utilizarei uma prova com questões objetivas sobre os conteúdos trabalhados pelo professor regente e os tópicos de termoquímica que trabalhei [...]" (grifo nosso).

[Semana 09 e 10] Objetivos: "Apresentar as diferentes fontes de energia utilizadas no Brasil (biomassa, carvão, hidráulica, nuclear, eólica, solar, derivados do petróleo)".

Metodologia: "Cada grupo terá 20 minutos para apresentar o trabalho. Farei duas perguntas sobre o assunto pesquisado para cada grupo, visando verificar 


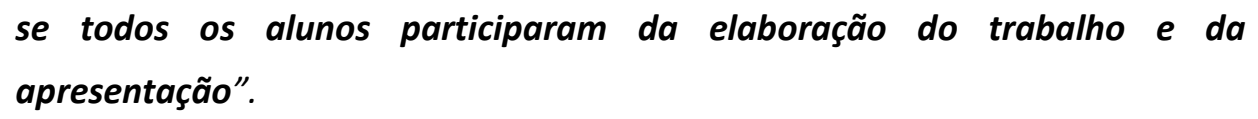

Avaliação: "Entrega e apresentação dos trabalhos sobre fontes de energia".

Diante das descrições acima, cabe destacar que Sil demonstrou uma posição clara da necessidade de verificação da efetivação dos objetivos buscados por ela nos planejamentos, principalmente quanto aos aspectos conceituais e procedimentais, apresentando coerência entre os instrumentos avaliativos e a metodologia utilizada nas aulas. Evidencia-se que Sil não referiu de que forma avaliaria efetivamente a qualidade da participação dos alunos. A licencianda apenas citou que registraria em uma planilha a realização ou não das atividades, conforme foi verificado durante as aulas observadas. Dessa forma, compreende-se que a valorização de quase todas as atividades propostas (realização de exercícios, apresentação de respostas e a realização de pequenas pesquisas bibliográficas) representa mais um fator motivacional, visando favorecer o envolvimento dos alunos nas aulas, do que avaliativo, com a finalidade de analisar a evolução do processo de aprendizagem dos alunos.

Ao analisar-se a prova utilizada, verifica-se que esta era composta por questões objetivas de aplicação direta dos conteúdos de termoquímica trabalhados em aula, contemplando também duas questões do Exame Nacional do Ensino Médio (ENEM) que relacionavam os conteúdos de termoquímica com biocombustíveis.

Diante do exposto, entende-se que a licencianda Sil considerou que seus instrumentos avaliativos deveriam testar objetivamente a aplicação dos conteúdos que foram trabalhados em aula, visando analisar o produto que pôde ser expresso na prova e apresentado no trabalho, acrescido da participação dos alunos nas atividades de aula que, em sua maioria, visavam à avaliação inicial e terminal dos conhecimentos dos licenciandos. Sendo assim, conclui-se que os procedimentos de Avaliação (PORLÁN e RIVERO, 1998) adotados por Sil aproximam-se do modelo didático Tecnológico.

\section{Evolução dos Modelos Didáticos e o reflexo das formas de contribuição do CLQ para o desenvolvimento profissional da licencianda}

Conforme se apresenta na Tabela 1, Sil demonstrou progredir em seu desenvolvimento profissional no segundo estágio, pois mesmo não se aproximando do modelo didático considerado desejável (Investigativo), ela empreendeu uma prática docente próxima à do modelo didático Tecnológico, para as quatro categorias de análise. Segundo Porlán e Rivero (1998), o modelo didático Tecnológico aponta uma evolução quanto às concepções epistemológicas e a prática docente dos professores que o utilizam, pois nesse modelo os professores reconhecem 
que há a necessidade de um processo de ensino diferenciado do tradicional transmissão e recepção do conhecimento.

Tabela 1. Categorias dos Planos de Trabalho da licencianda Sil

\begin{tabular}{ccc}
\hline Categorias & Estágio IA & Estágio IIA \\
\hline Conteúdos Escolares & TRA & TEC \\
$\begin{array}{c}\text { Tipos de Atividades e } \\
\text { Recursos Didáticos }\end{array}$ & TRA/TEC & TEC \\
Uso Didático da Perspectiva & TRA/TEC & TEC \\
dos Alunos & & \\
Avaliação & TRA & TEC \\
\hline
\end{tabular}

Onde TRA = tradicional; TEC = tecnológico; INV = investigativo.

No segundo estágio, verifica-se que as estratégias de ensino de Sil visavam ao desenvolvimento dos âmbitos conceituais e procedimentais, pois ela utilizou uma sequência de atividades voltadas à exposição, demonstração ou comprovação das teorias estudadas, objetivando facilitar a assimilação dos conhecimentos científicos, por parte dos alunos. Logo, compreende-se que, mesmo que ela tenha começado a considerar as ideias e os interesses dos alunos para elaborar suas aulas nesse segundo estágio, Sil buscava a adequação desses conhecimentos prévios às teorias da Ciência. Adequação no sentido de corrigir os conceitos prévios dos alunos, além de citar que coletaria as ideias dos estudantes como forma de motivá-los a participarem das aulas, como o fez, conforme registros do Diário de Campo. Dessa forma, entende-se que as concepções epistemológicas de Sil, no segundo estágio, correspondem às de cunho absolutista da ciência, com enfoque empiro-indutivista, que fundamentam o modelo didático Tecnológico.

Sendo assim, compreende-se que mesmo frente à evolução para um estágio intermediário do desenvolvimento profissional, Sil ainda não concebe o papel epistêmico das ideias prévias dos alunos no processo de aprendizagem, resultado próximo aos encontrados na literatura (FLORES et al., 2000; MELLADO, 2001; HARRES et al., 2005; PREDEBON e DEL PINO, 2009). Além disso, de acordo com os apontamentos do Diário de Campo, durante os dois estágios, ela não considerou a contribuição da interação discursiva entre alunos e alunos, alunos e professor, conhecimentos cotidianos e científicos, como fatores que contribuem para a complexificação dos conhecimentos escolares dos seus alunos.

Diante desse conjunto de constatações, infere-se que Sil encontrou dificuldades para progredir para níveis mais avançados do itinerário de progressão do conhecimento profissional, mesmo vivenciando ações formativas, durante os estágios, que contribuíram para esse processo.

206 DOI: Em andamento.

R. Bras. de Ensino de C\&T 
Conforme identificado em estudos anteriores (PASSOS; DEL PINO, 2013), as atividades dos Estágios Curriculares Supervisionados favorecem a reflexão sistemática sobre as teorias de ensino e aprendizagem, estudadas durante o CLQ, com os conflitos de sala de aula, as concepções epistemológicas e as influências dessas nos resultados das práticas docentes desenvolvidas nas escolas.

Considerando as contribuições de Porlán e Rivero (1998), ao descreverem o conhecimento profissional como resultante da associação de saberes de dimensão epistemológica (acadêmicos e experiências) e de dimensão psicológica (rotinas e guias de ação, e teorias implícitas), compreende-se que um conjunto de fatores em sinergismo pode ter contribuído para que Sil não tenha progredido para níveis mais avançados do desenvolvimento profissional.

Primeiramente, salienta-se que o modelo formativo oferecido pelo CLQ pode ter reforçado as concepções simplistas (de fundo absolutista) identificadas no Plano de Trabalho produzido por Sil no primeiro estágio, sobre os processos de ensino e de aprendizagem, e, sobre o papel dos alunos e do professor em sala de aula. Em estudo sobre as formas de contribuição das diferentes disciplinas do CLQ para a formação profissional dos licenciandos (PASSOS; DEL PINO, 2012), verificou-se que os procedimentos didáticos vivenciados nas disciplinas de conhecimentos específicos de Química e área afins satisfazem ao modelo didático Tradicional. Neste sentido, os futuros professores participam de ações formativas nas quais o conhecimento acadêmico é priorizado dentre os demais que compõem o conhecimento profissional do professor.

Além disso, considera-se que a prática docente de Sil também pode estar relacionada à influência de suas vivências escolares anteriores às acadêmicas, pois a licencianda foi aluna de um curso técnico em Química.

Ademais, a falta de oportunidades de vivenciar o papel de professora de Química em ambiente escolar em etapas anteriores a dos estágios, protelou o início do processo de amadurecimento profissional da licencianda. Destaca-se que se percebeu uma progressão dos modelos didáticos de Sil do primeiro para o segundo estágio, indicativo de que as atividades formativas vivenciadas no período final do curso contribuíram para o desenvolvimento profissional dessa licencianda.

Ainda, considerando o caráter subjetivo do processo, enfatizam-se as contribuições da influência da história de vida profissional da licencianda. Sil entrou em um curso de licenciatura, não pelo desejo de tornar-se educadora, mas sim, porque considerou o CLQ como uma nova oportunidade de inserção no mercado de trabalho, frente a decepções na antiga área de atuação.

Cabe lembrar que Sil, no período em que participou da investigação, era bolsista de IC na Área de Educação Química (AEQ). Portanto, justifica-se que ela pode ter sofrido influências das leituras e investigações com as quais estava tendo contato em suas atividades na $A E Q$, fato que pode ter contribuído de forma significativa para o avanço no itinerário de progressão. Todavia, 
conforme os relatos de Sil, ela não teve experiência como professora antes dos estágios, logo, mesmo tendo contato com os aportes teóricos da área de ensino de Química, ela pode não ter conseguido colocá-los em prática no momento de estruturar seus planejamentos.

Conforme apontamentos na literatura (BEJARANO e CARVALHO, 2003; PORLÁN, et al., 2010; PREDEBON e DEL PINO, 2009) e a vivência dos autores deste trabalho como formadores de professores, verifica-se que é comum que os professores em formação ou iniciantes na profissão foquem suas propostas de trabalho na transmissão dos conteúdos disciplinares. Entende-se que tais ainda não apresentam segurança, maturidade e subsídios para fazer uso de um modelo didático nunca antes vivenciado por eles no papel de alunos, como o Investigativo. Dessa forma, considera-se que Sil demonstrou avanços significativos em seu processo de amadurecimento profissional durante esta investigação.

Neste sentido, mesmo que este Estudo de Caso (LÜDKE e ANDRÉ, 1986) apresente limitações por se tratar do acompanhamento e análise das produções e práticas de uma licencianda, destaca-se que os resultados identificados nesta investigação podem servir de subsídios para o acompanhamento do processo evolutivo do conhecimento profissional de outros licenciandos. Apresenta-se essa consideração, pois o CLQ vivenciado pela licencianda corresponde a um sistema de ensino que está intrinsecamente arraigado em estruturas culturais, econômicas, ideológicas e epistemológicas, ou seja, a um sistema social amplo e complexo que se correlaciona com os demais Cursos de Licenciatura em Química brasileiros.

\section{Conclusão}

Como guisa de conclusão, verifica-se que durante o período dos estágios, Sil demonstrou uma mudança gradual de suas concepções epistemológicas de cunho absolutista e reducionista da ciência, mantendo ainda uma visão de fundo absolutista, porém com enfoque empiroindutivista que fundamenta o modelo didático Tecnológico. Todavia, mesmo progredindo para estágios intermediários da Hipótese de Progressão do conhecimento profissional (PORLÁN e RIVERO, 1998), entende-se que o conjunto de concepções epistemológicas de Sil, identificadas no primeiro estágio, serviu como obstáculo à sua progressão para níveis mais avançados do processo de desenvolvimento profissional.

Salienta-se que a licencianda pode não ter conseguido reformular totalmente suas concepções e práticas, em apenas dois semestres de estágio. Entretanto, destaca-se que as atividades de natureza investigativa sobre as rotinas de sala de aula à luz da literatura, durante os estágios, favoreceram a reflexão sobre as interações entre as concepções e práticas. Sendo assim, entende-se que contribuíram para o processo de aperfeiçoamento do conhecimento profissional da licencianda.

208 DOI: Em andamento.

R. Bras. de Ensino de C\&T 
Nesse âmbito, infere-se que o processo formativo cursado por Sil, antes dos estágios, pode ter reforçado suas concepções epistemológicas de cunho absolutista e reducionista quanto aos processos de ensino e de aprendizagem. Destaca-se essa hipótese, visto que a licencianda utilizou o interesse dos alunos apenas para motivá-los a participar das aulas, e por não ter demonstrado considerar o papel epistêmico dos conhecimentos prévios deles, para a elaboração do seu Plano de Trabalho. Acrescido a isto, Sil demonstrou conceber, em seus planejamentos, que os conteúdos científicos são as fontes determinantes dos conhecimentos escolares, pois não fez ou não teve elementos para realizar relações desses com os conhecimentos dos alunos e com os referentes sociais, ambientais, culturais ou econômicos envolvidos nesses. Portanto, entende-se que o CLQ pode ter reforçado para Sil que o papel do aluno é o de absorver os conhecimentos disciplinares, sem ter grande participação no processo de aprendizagem e que o do professor é o de transmitir esses conhecimentos para os alunos de forma que eles consigam assimilá-los.

Enfim, conclui-se que os professores aprendem sobre sua profissão durante toda a sua história, desenvolvendo suas concepções epistemológicas sob a influência do meio escolar, social, cultural, econômico e acadêmico vivenciados. Alguns se desenvolvem mais rapidamente e enfrentam os conflitos da prática docente de maneira mais flexível, no que diz respeito à análise dos diversos fatores que os geraram, e na busca por alternativas de melhores resultados para a aprendizagem dos alunos. Os educadores que adotam essa postura profissional, que se entende como personalíssima dos indivíduos, muitas vezes conseguem reformular as concepções que embasam sua atividade profissional (BEJARANO e CARVALHO, 2003; HARRES et al., 2005; RODRIGUES et al., 2010). Em contrapartida, outros sujeitos, como a licencianda Sil, podem enfrentar maiores dificuldades em lidar com seus conflitos, concepções e os resultados de suas atuações como educadores, experimentando um desenvolvimento profissional mais lento, por não conseguirem relacionar os diferentes fatores que subjazem aos processos de ensino e aprendizagem.

\section{Referências}

ANDRÉ, M. A Pesquisa Sobre Formação de Professores: contribuições à delimitação do campo. In: DALBEN; Â.I.L.F.; DINIZ, J.; LEAL, L.; SANTOS, L. (Org.). Convergências e tensões no campo da formação e do trabalho docente. Belo Horizonte: Autêntica, 2010. p 273-287.

BEACH, R.; PEARSON, D. Changes in preservice teachers' perceptions of conflicts and tensions. Teaching e Teacher Education, v. 14, n. 3, p. 337-351, 1998.

BEJARANO, N. R. R.; CARVALHO, A. M. P. Tornando-se professor de ciências: crenças e conflitos. Ciência e Educação, v.9, n. 1, p. 1-15, 2003.

BOGDAN, R. E BIKLEN, S. A Investigação Qualitativa em Educação. Porto: Porto Editora, 1994. 
BRASIL. Ministério da Educação. Conselho Nacional de Educação. Resolução CP no 01/02, de 18 de fevereiro de 2002. Institui as Diretrizes Curriculares Nacionais para a Formação de Professores da Educação Básica, em nível Superior, curso de licenciatura de graduação plena.

CARVALHO, A.M.P.; GIL-PÉREZ, D. Formação de Professores de Ciências: tendências e inovações. São Paulo: Ed. Cortez, 2006. 120p.

FLORES, F.; LÓPEZ, A.; GALLEGOS, L.; BAROJAS, J. Transforming science and learning concepts of physics teachers. International Journal of Science Education. v. 22, n. 2, p. 197-208, 2000.

GARCÍA PÉREZ, F.F. Los modelos didácticos como instrumento de análisis y de intervención en la realidad educativa. Revista Bibliográfica de Geografía y Ciencias Sociales. Universidad de Barcelona, n.207. 2000. Disponível em <http://www.ub.es/geocrit/b3w-207.htm>. Acesso em janeiro de 2014.

HARRES, J.B.S; PIZZATO, M.C. Uma Experiência Inovadora de Prática Pedagógica na Formação Inicial de Professores. Contexto \& Educação. Ijuí, ano 22, n. 77, p. 51-80, 2007.

HARRES, J.B.S; PIZZATO, M.C.; SEBASTIANY, A.P.; PREDEBON, F.; FONSECA, M.C.; HENZ, T. Laboratórios de Ensino: inovação curricular na formação de professores de ciências. Santo André: ESETec Editores Associados, 2005.

HARRES, J.B.S; PIZZATO, M.C.; SEBASTIANY, A.P.; PREDEBON, F.; FONSECA, M.C. Evolução das concepções de futuros professores sobre a natureza e as formas de conhecer as ideias dos alunos. Revista Brasileira de Ensino de Ciência \& Tecnologia, v. 1, n.2, p.95-112, 2008.

KAGAN, D. M. Professional growth among preservice and beginning teachers. Review of Educational Research, v. 62, n.2, p.129-169, 1992.

LEDERMANN, N.G.; ZEIDLER, D.L. Science teacher's conceptions of the nature of science: do they really influence teaching behavior? Science Education, v.71, n.5, p.721-734, 1987.

LÜDKE, M.; ANDRÉ, M.E.D.A. Pesquisa em Educação: Abordagens Qualitativas. São Paulo: EPU, 1986.

MANSOUR, N. Science Teachers' Beliefs and Practices: Issues, Implications and Research Agenda. International Journal of Environmental \& Science Education. v.4, n.1, p. 25-48, 2009.

MELLADO, V. ¿Por qué a los profesores de ciencias nos cuesta tanto cambiar nuestras concepciones y modelos didácticos? Revista Interuniversitaria de Formación del Profesorado, n.40, p.17-30, 2001.

NOVAIS, R.M.; MARCONDES, M.E.R. Investigando alguns reflexos das disciplinas de Instrumentação para o Ensino de Química na formação inicial de professores. In: Anais do XIV Encontro Nacional de Ensino de Química, 2008, Curitiba. Anais... XIV ENEQ, Curitiba, 2009.

210 DOI: Em andamento. 
OLAFSON, L.; SCHRAW, G. Teachers' Beliefs and Practices within and across domains. International Journal of Educational Research, v.45, p.71-84, 2006.

PASSOS, C.G. O Curso de Licenciatura em Química da UFRGS: conquistas e desafios frente à reformulação curricular de 2005. Tese de Doutorado em Educação Química - Universidade Federal do Rio Grande do Sul, UFRGS, Porto Alegre/RS, 2012.

PASSOS, C.G.; DEL PINO, J.C. As formas de contribuição dos Estágios Supervisionados do Curso de Licenciatura em Química da UFRGS para o desenvolvimento profissional dos licenciandos. Revista Contexto \& Educação. No prelo, 2013.

PASSOS, C.G.; DEL PINO, J.C. Curricular Reformulations in Early Chemistry Teacher Formation: The Experience in a Brazilian Federal University. Journal of Science Education - Revista de Educación en Ciencias. v. 13, n.1, 2012.

PORLÁN, R.; MARTíN, J. El diario del profesor: Un recurso para la investigación en el aula. 6 ed. Sevilla:Díada, 1998.

PORLÁN, R.; MARTíN, D.P.R.; RIVEIRO, A.; HARRES, J.; AZCÁRATE, P.; PIZZATO, M. El Cambio del Profesorado de Ciencias I: marco teórico y formativo. Enseñanza de Las Ciencias. v. 28, n. 1, p. 3146, 2010.

PORLÁN, R.; RIVERO, A. El conocimiento de los profesores. Sevilla: Díada, 1998.

PRAIA, J.F.; CACHAPUZ, A.F.C.; GIL-PÉREZ, D. Problema, Teoria e Observação em Ciência: para uma reorientação epistemológica da educação em ciência. Ciência \& Educação, v.8, n.1, p.127-145, 2002.

PREDEBON, F.; DEL PINO, J.C. Uma análise evolutiva de Modelos Didáticos associados às concepções didáticas de futuros professores de Química envolvidos em um processo de intervenção formativa. Investigações em Ensino de Ciências. v.14, n.2, p. 237-254, 2009.

RODRIGUES, C.G.; KRÜGER, V.; SOARES, A.C.; Uma hipótese curricular para a formação continuada de professores de ciências e de matemática. Ciência \& Educação, v. 16, n. 2, p. 415-426, 2010.

SCHNETZLER, R. A Pesquisa em Ensino de Química no Brasil: Conquistas e Perspectivas. Química Nova, v.25, n.1, p.14-24, 2002.

SOARES, I.M.F.; BEJARANO, N.R.R.; Crenças dos professores e formação docente. Revista da FACED, Salvador, n.14, p.55-71, jul./dez. 2008.

UFRGS. Comissão de Graduação em Química. Projeto pedagógico para a licenciatura em química da UFRGS. Porto Alegre, 2005.2 Disponível em <http://www.iq.ufrgs.br/graduacao/informacoesgerais> Acesso em janeiro de 2014.

YIN, R.K. Case Study Research: design and methods. London: SAGE Publications, 2009, 222p. 
ZABALA, A. (1998). A prática educativa: como ensinar. Porto Alegre: Artes Médicas.

ZEICHNER, K.M. Uma Agenda de Pesquisa para a Formação Docente. Formação Docente - Revista Brasileira de Pesquisa sobre Formação Docente. v. 1, n.1, p. 13-40, 2009.

Camila Greff Passos - Doutora em Educação Química pela Universidade Federal do Rio Grande do Sul (UFRGS). Professora adjunta do Departamento de Química Inorgânica do Instituto de Química e orientadora no Programa de Pós-Graduação em Química (PPGQ) da Universidade Federal do Rio Grande do Sul (UFRGS).E-mail: camila.passos@ufrgs.br

José Claudio Del Pino - Pós-doutor em Educação pela Universidade de Aveiro-Portugal. Professor associado da Universidade Federal do Rio Grande do Sul (UFRGS). Professor-Orientador do PPG Educação em Ciência Química da Vida e Saúde e do PPG Química ambos da Universidade Federal do Rio Grande do Sul (UFRGS). E-mail: delpinojc@yahoo.com.br 